\title{
17. Obtuse anglers: The linguistics and ethnography of fishing ground names on Norfolk Island
}

\author{
Joshua Nash \\ University of Adelaide
}

\begin{abstract}
When I first lived in Arviat [Canada], the sea was a blank space to me. I did not know the names of the headlands, the reefs, the islands, or the other places along the coastline. I did not know the stories associated with the sea, and I had no personal experiences on the sea. In the beginning I was utterly confused. My journeys on the open water or sea ice were disorienting. I did not know where I was or where I was going, and I relied completely on the hunters with whom I travelled. However, as time moved on, I began to develop an understanding of the sea. I became familiar with the places along the coastline, and I began to hear the stories that were situated in specific places. I began to make connections between these places, and I began to have memorable experiences of my own in specific places at sea. (Tyrell 2006: 228)
\end{abstract}

\section{At sea}

The toponymic processes involved in the naming of fishing grounds represent significant examples of place-creation. They are brought into existence by the human need to name and remember locations at sea. These utilitarian placenames are rarely mapped; they are easily forgotten and are some of the most ephemeral aspects of a people's toponymic inventory:

It is not much use taking bearings if they are not accurately recorded for future reference. The human memory for such details is fickle and the eye is easily deceived. ... It is asking a lot to try to carry details of 4 points in the mind for each fishing point that may be worked. It is imperative that they be recorded, and it is a good idea to mark them on an Admiralty chart in similar manner [sic] to that used in our sketch. (Hardy 1974: 227)

Fishing ground names are a subcategory of hydronyms, names for water features. They are transient cultural capital; the offshore location of these no places which become place(s) through naming can be lost when terrestrial markers, such as 
trees and houses, are altered or removed. As I will demonstrate, there is a large amount of grammatical variation in the linguistic form and cultural status of fishing ground names. Despite a large amount of interest in the anthropology of fishing (Acheson 1981) and specifically the anthropology of fishing in Oceania (Johannes 1981), there has been little interest in the relationship between the naming of fishing grounds and the relevance of these names to formal linguistic and ethnographic analysis.

This paper is divided up as follows: the historical and theoretical background into the role of fishing ground names in toponymy is given; the relevance of fishing ground names to Norfolk toponymy and Norf'k, the Norfolk Island language, is outlined; a tagmemic analysis of Norf'k fishing ground forms is presented to account for the formal structure of these names; an analysis of a single fishing ground name is used to explore the role Norf'k fishing ground names hold in Norfolk toponymy as a whole and how fishing ground names can contribute to the writing of Norfolk's toponymic ethnography. To the best of my knowledge, a similar analysis has never been attempted in Australia or elsewhere. The closest study is given in Blair (2006). ${ }^{1}$

\section{Collecting no-names}

To collect fishing ground names I dealt with older members of the Norfolk population. I utilised maps when interviewing knowledgeable people and asked whether they remembered places, who lived there, who named the places, and what activities were carried out in these places. Many remember the names of places and their locations but in many cases they did not know who named them, and why they were named such. I would often probe in order to understand how people came to acquire esoteric knowledge such as fishing ground locations. Informants told me they would simply go out fishing with the old fishermen when they were around ten years old and the old fisherman told the younger men where the old places were. The men knew who Johnnies and Frankies were named after; they worked with them, had a beer with them after work, and their children played together. Because of the insular nature of Norfolk as a closed, island society, an insular toponymy developed. This insular toponymy served not only a linguistic and practical social function involving communication - they became vital economic tools and provided a means of adapting ecologically to a place. Fieldwork in these places is a reliable method to access this insider knowledge and these insular toponymies.

1 My analysis draws heavily on Nash (2011: 136-145). Fishing ground data is given in an appendix to this document which can be found at http://digital.library.adelaide.edu.au/dspace/handle/2440/71015. 
Nine fishermen (only males) were interviewed over 15 interviews to compile a corpus of fishing ground names and historical information. In order to carry out this process I liaised with and interviewed five Norfolk fishermen over three field trips in 2008 and 2009. These interviews involved creating an offshore map of Norfolk which incorporated both the plotting of locations to names and documenting the history of these names. Seventy-three fishing ground names were elicited during this time. Obtaining fishing ground name data was initially a sensitive issue. This was because the location of these names had traditionally been almost sacred insider knowledge that would not normally be shared with the community. These fishermen are obtuse anglers. Their knowledge is obtuse, the angles used to line up fishing grounds are astute. After I had established rapport with the group of fishermen with whom I worked intently, both onshore and offshore, I could freely ask questions about their fishing grounds. Common questions I posed to the fishermen were: what is the name of the fishing ground?, who named it and when was it named?, where is it and how do you locate it?, and what kinds of fish would you catch there?

My field research on Norfolk Island with fishermen who still remember and use these fishing marks and the visual triangulation system has shown that knowledge of these fishing marks is exclusively the realm of the older predominantly male members of this community. This knowledge is not gender specific per se. But because few women fish on Norfolk Island, women have less access to fishing ground knowledge. Any such knowledge, if known to women at all, typically consists of a few common names that are overheard when spoken by male relatives or associates. While the map presented in map 4 depicts fishing ground locations as accurately as possible, it is the cultural and ecological links to language and place that are integral to this paper rather than exact locations.

\section{Norf'k introduced}

Norf'k stems from the language which emerged on Pitcairn Island from 1790 in a small community comprised of Tahitian and English speakers. All the Pitcairn Islanders were moved to Norfolk Island in 1856. This marks the beginning of Norf' $\mathrm{k}$ as a form of the language of Pitcairn which has undergone changes due to its transplantation to a new environment.

Norf'k is spoken by around 300 people on Norfolk Island. As an endangered language recognised by the United Nations Educational, Scientific and Cultural Organization (UNESCO 2007), and the only other language within Australia and its territories co-official with English with the passing of the Norfolk Island Language (Norf'k) Act (2004) (Administration of Norfolk Island 2004), 
Norf'k is a key element of Australia's linguistic and cultural heritage. Various social and political stigmas associated with the language during the last 100 years, especially in the education system (Mühlhäusler 2007), have meant the language has suffered severely. Documenting Norf'k fishing ground names is not only important for documenting an important element of the lexicon of an endangered language, but also in putting forward fishing ground names as a key aspect of a language's placename lexicon which deserves theoretical consideration. Norf'k fishing ground name data are extremely valuable to the Norfolk Island community.

\section{Fishing ground name analysis}

A quote from Forman contextualises the status of fishing ground names:

The fishermen of the Coqueiral [Brazil] share a generalized knowledge of the area of the sea and the aspect of the land which comprise their fishing universe. The possibility of maximizing individual production rests on their ability to locate particular species of fish according to market values in different seasons. Towards this end they have elaborated a complex system of named fishing grounds and landmarks. The location of the fishing grounds by visual triangulation and the knowledge of the distribution of fish within them in given seasons are transmitted over generations. (Forman 1967: 417)

Apart from Capel's (1977) description of colloquial names for fishing grounds in coastal South Australia, the most comprehensive descriptions of fishing ground names are Hovda (1961) for the western coast of Norway and Forman (1967) for mangrove-based fishing in areas of coastal Brazil. Blair's (2006) account of the neighbourhood-based narrative of fishing shots in the Gippsland Lakes in Victoria and Gaffin's (1996) analysis of fishing grounds in the Faeroe Islands as part of his ethnography represent the key significance of fishing ground names as a part of oral culture and memory rarely documented by ethnographers. Blair lists fishing shot names like 'Gilly's Snag', 'Silver Shot Slunk' and 'Coaler's Rack'; Gaffin gives Faeroe Islands names like 'Shag Bank' and 'Aksal's Spot'.

Norfolk fishing ground names have arisen in relation to particular elements of Norfolk's topography and represent an intimate relationship between language, landscape, and culture where toponymy is viewed as a useful access point. It is worth remembering Mühlhäusler's statement:

Memories are not factual records of events but socially negotiated. Etymologising for any language is a mixture of factual information and socially acceptable accounts. (Mühlhäusler 2006: 110) 
Fishing is an important livelihood and defining cultural activity on Norfolk. However, modern GPS technology and a decreased need to depend on fishing for sustenance mean many of these names are just a memory, which is quickly fading. Two quotes from Kurlansky's (1999) depiction of pioneering fishermen in North America in his book Cod: A Biography of the Fish that Changed the World illustrate the need to document the cultural significance of fishing ground names against the inevitability of loss over time:

These are the fishermen who stand sentry over the cod stocks off the headlands of North America, the fishermen who went to sea but forgot their pencil. (Kurlansky 1999: 1)

Only today, having forgot a pencil, they head over to the other boat where the three-man crew is already hauling cod with handlines. After a few jokes about the size of this sorry young catch, someone tosses over a pencil. They are ready to fish. (Kurlansky 1999: 3)

Norfolk fishing ground names are culturally elaborate and significant. Many of these are shallow reefs and crevices and have been found through experimentation and trial and error over time. It becomes clear when interviewing older people on Norfolk Island that people know fishing ground names exist and were and are still used. Most people, however, do not know the names, the history of the names, e.g. who named them first and who continues to use them, why some names were named in the way they were, and where fishing grounds are located. This could be due to several reasons, the most obvious being lack of usage, loss of memory, and secrecy:

A fisherman rarely teaches the art of lining up a specific fishing spot, and a boy's apprenticeship consists largely of curiosity and persistence. While a fisherman is always delighted to have a young apprentice help to augment his catch, he avoids taking him to a preferred spot. (Forman 1967: 422)

Shallow Water came into being through trial and error from fishing experience and was passed down through generations. It exists as a non-exact even transient offshore location created through intimate knowledge of the sea and its location in terms of the terrestrial topography:

Just at the start of No Trouble you find Shallow Water. When you line the Alligators Eye with Mount Pitt and follow that line out until you get a little narrow gap in the pine trees at Byron Burrell's place at Duncombe Bay near the Captain Cook Memorial. The reef is very shallow and comes up to about 35 metres depth. Shallow Water is the general name of a fishing area which covers about a mile square. (Bev McCoy, Norfolk Island, 2009) 
Capel's (1997: 5) description of 'Fred's Ground', named after the shark which was once seen in the area offshore from Adelaide (Map 1), and Hovda's (1961: 257) description of the fishing ground 'Seta' off the shores of Karmøya near Stavanger on the west coast of Norway (Map 2) depict how names of fishing grounds prior to GPS were located, recorded, and remembered.

Fishing off the coast of Norfolk Island has taken place for more than a century. There is no extant fishing ground knowledge used before 1856 . While there were possibly fishing grounds located and used prior to 1856, my informants were not aware of any of these names or locations. However, it is likely any offshore fishing would have used similar grounds and similar triangulation techniques to those used by the Pitcairners after they arrived on Norfolk. Göthesson (2000) lists several Pitcairn fishing grounds, e.g. 'Side for Parkin's', 'Pulawana Bank', and communication with Pitcairn Islanders indicates there is a similar system of triangulation on Pitcairn:

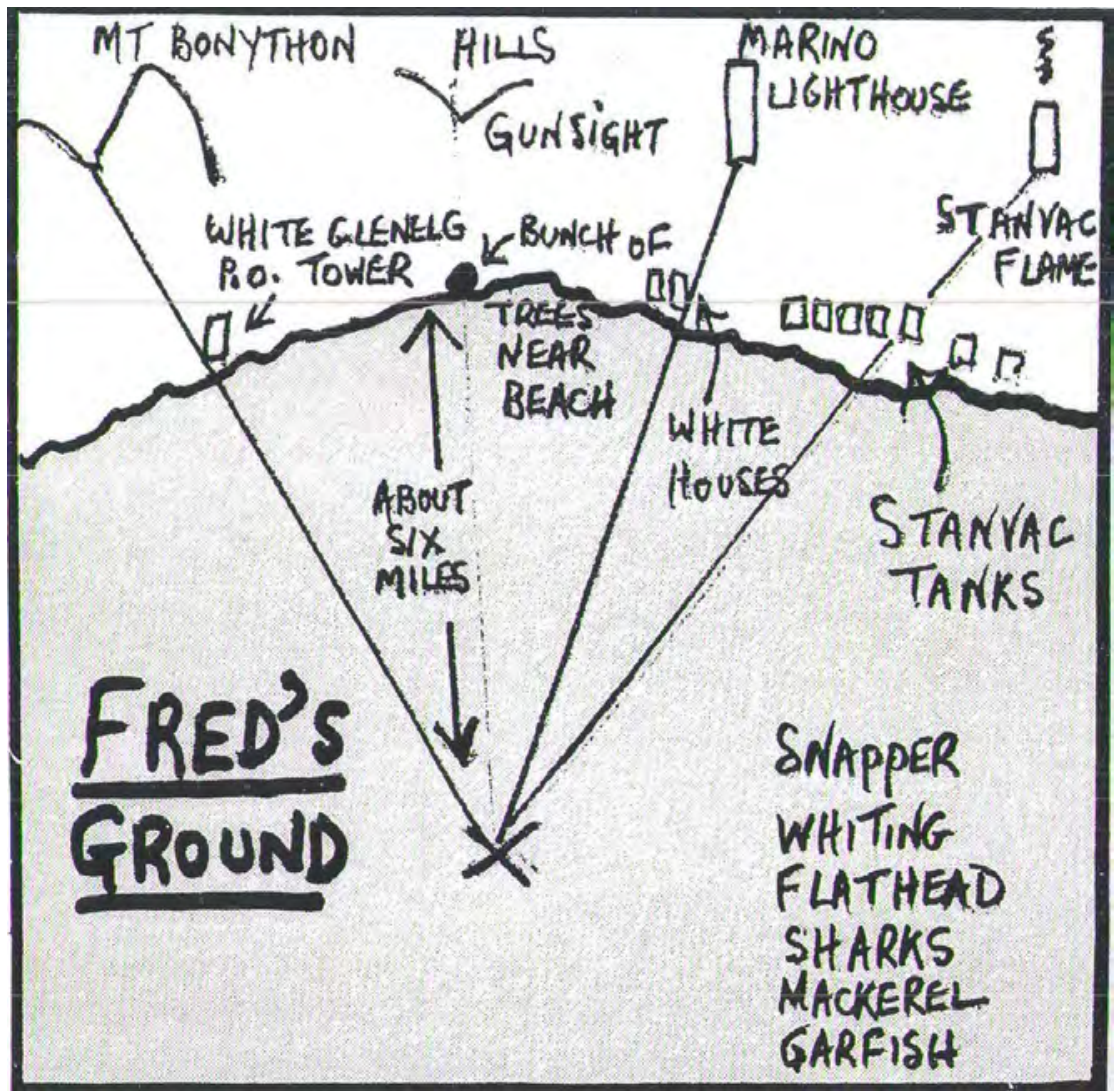

Map 1: Map of 'Fred's Ground' off the coast of Adelaide.

Source: Capel (1997: 5). 


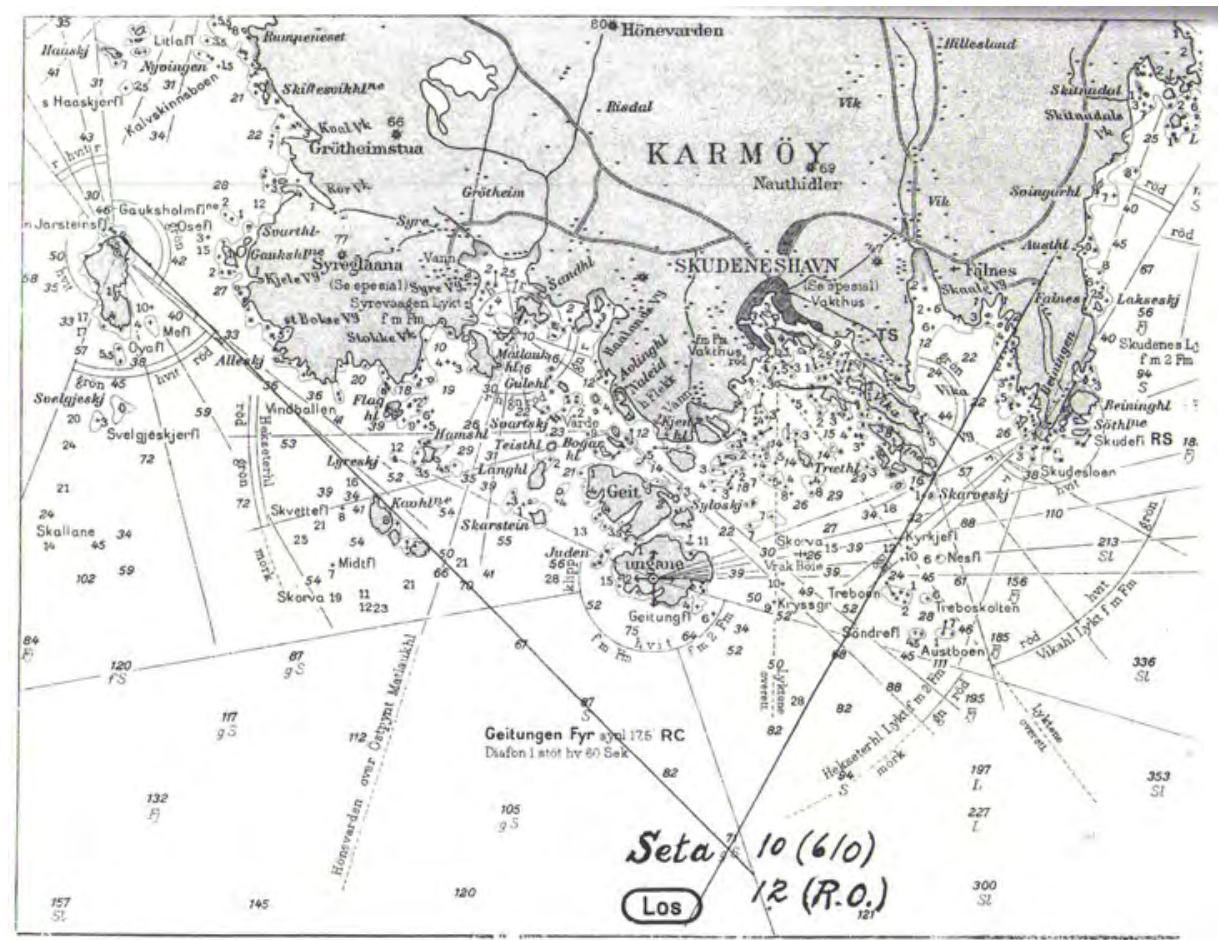

\section{Map 2: Map of location of the fishing ground 'Seta' off Karmøya, Norway.}

Source: Hovda (1961: 257).

We have many names offshore, e.g. 'Har road fer Cookies', 'Har Rooster', 'Out har Bear', 'Har Speckle Side', 'Headache', 'Matt en Dowley'. The marks are taken from ridges or trees lined up with the coastline or Island. These have been passed down through the generations. (Meralda Warren, email, 24 March 2008)

Starting with oared boats, then single piston motors that enabled fishermen to travel further away from the island, and eventually boats that could travel up to 30 kilometres away from Norfolk for commercial fishing, fishermen still rely on distinct landmarks on Norfolk to gain offshore bearings. When trees are chopped down and other landmarks such as houses and electricity poles are removed, marks are lost. Image 1 shows how Norfolk's coastline appears from the sea and some of the terrestrial features fishermen use when lining up fishing grounds: 

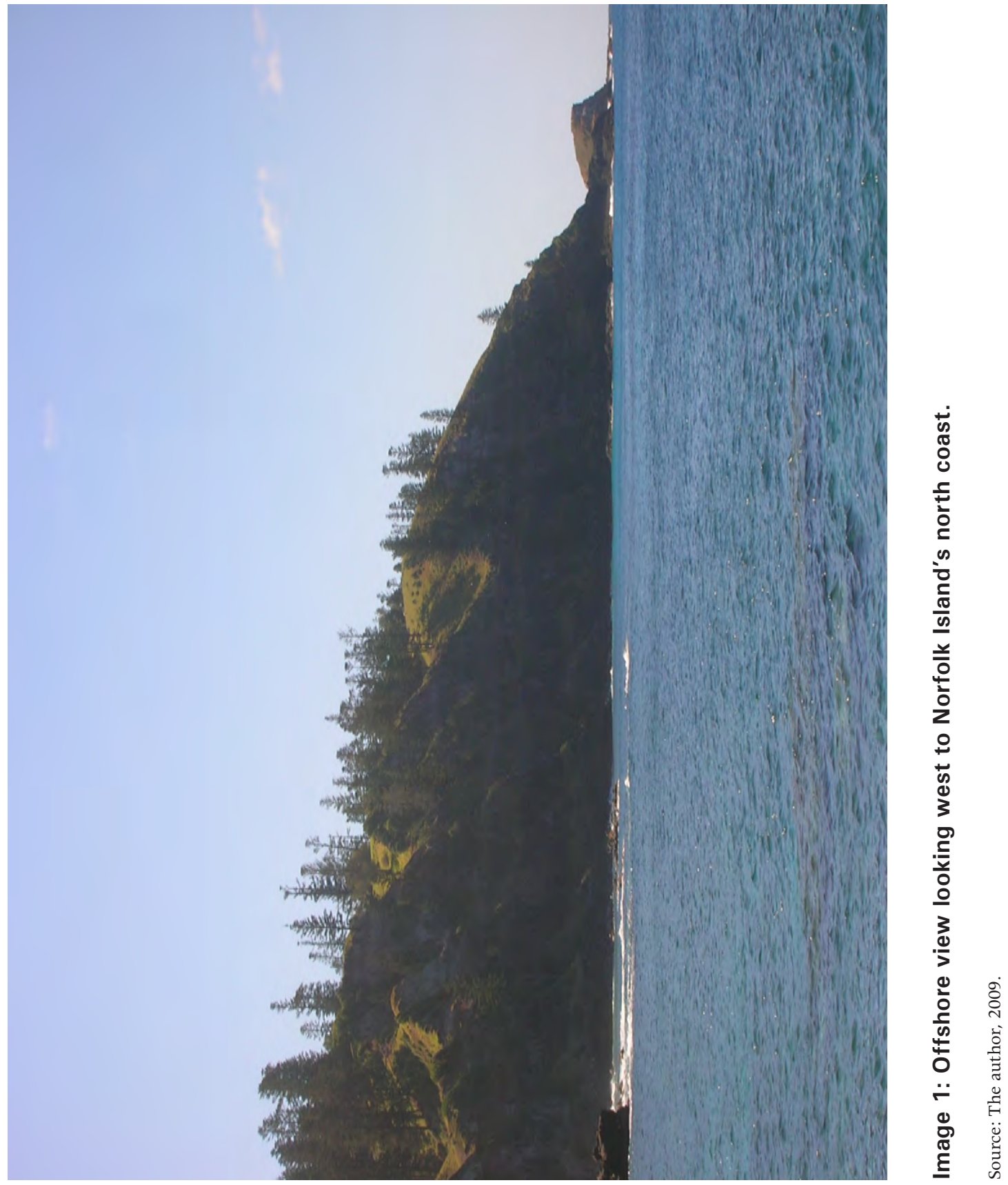
A map documenting Norfolk fishing ground names is given in Map 3.

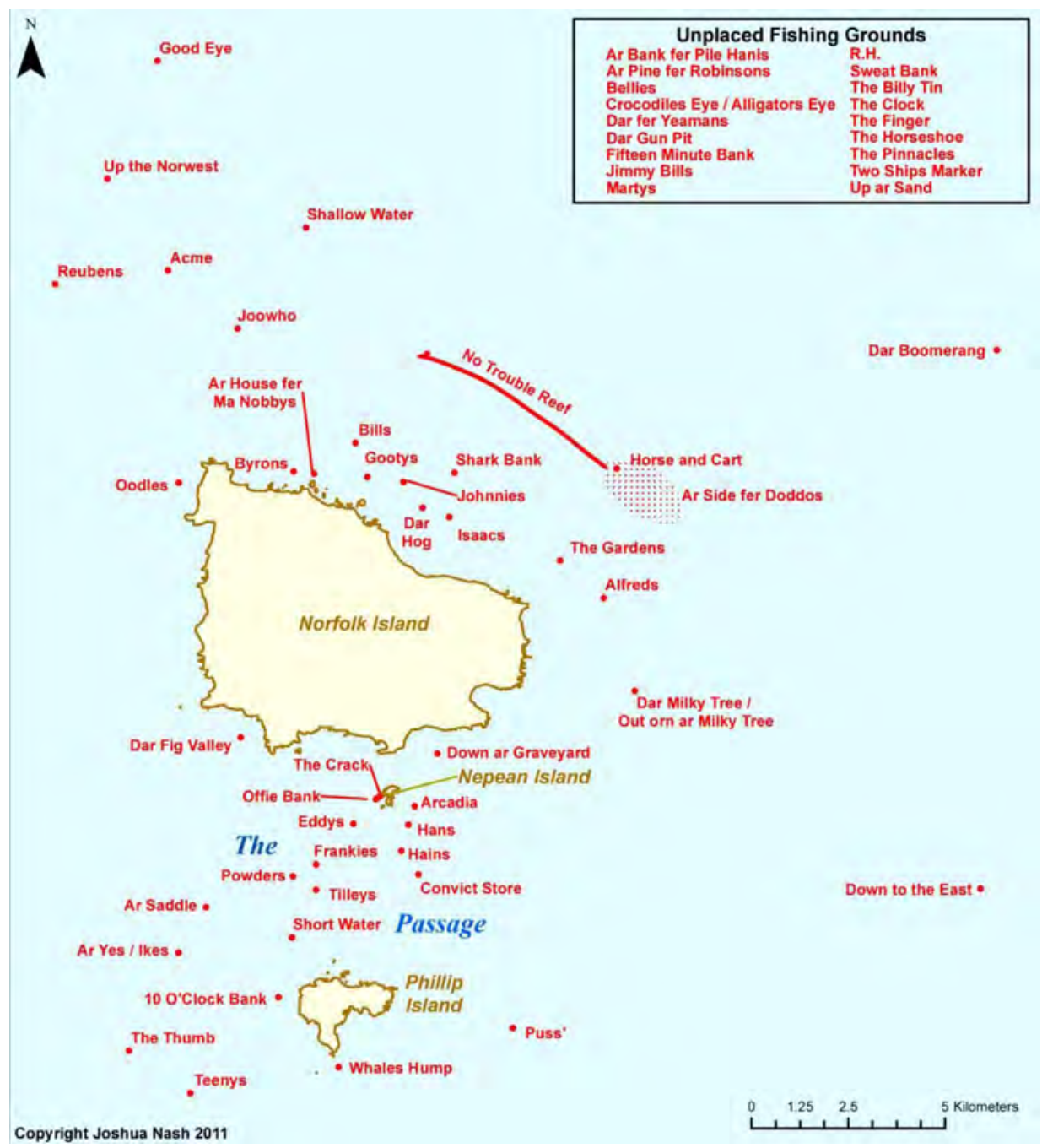

\section{Map 3: Norfolk Island fishing ground names map.}

Source: The author, 2011.

While Map 3 presents fishing grounds as fixed locations, their positions are variable and commonly cover large tracts of open ocean. The geographical patterns in this map are:

1. Most of fishing grounds are located close to the two major launching piers on Norfolk Island, Kingston (south) and Cascade (north). 
2. Getting to the majority of grounds does not require much travel. As a result, the grounds closer in to shore are older and grounds further from Cascade or Kingston are newer. This is because there was a need to search out newer grounds after older grounds were gradually fished out.

3. There are many fishing grounds in The Passage. Due to the volcanic nature of the Norfolk Ridge (Green 1973), there are many reefs located just beneath the surface of the ocean, especially near Nepean Island and Phillip Island.

There are a number of linguistic patterns in the fishing ground data:

1. Fishing ground names can be named after people and usually take the form of a proper noun + possessive, e.g. Powders, Tilleys, Frankies. Other syntactic variants occur in connection to the obligatory semantic component, e.g. Powders can occur as Dar Side fer Powders or Dar fer Powders (see section 5 tagmemic analysis).

2. Uninflected proper nouns can be fishing grounds, e.g. Acme (a boat used for fishing), Arcadia (named after the passenger ship Arcadia, which passed by when this ground was named).

3. ((English/Norf'k) definite article) + noun (+ noun) is productive, e.g. The Crack, The Gardens, The Thumb, Ar Saddle, Dar Milky Tree, Dar Fig Valley, Dar Boomerang, Convict Store, Offie Bank ('offie' is the Norf'k name for the fish, trevally). These are all descriptive names which describe either the water surrounding the ground, e.g. The Gardens, or terrestrial features used in lining up marks, e.g. Dar Horg. (Looking back to Norfolk on this mark, there is a topographical feature in the cliff which looks like a big black hog lying down.) $A r$ and dar are in free variation in all these forms. Choice is determined by certain pragmatic constraints, i.e. when Norf'k is spoken, Norf'k articles are used.

4. Animal and plant names can be metaphorically applied to fishing grounds, e.g. Whales Hump (named such because it uses the topographical feature of the same name in its marks), The Gardens (named after the seaweed found in the area).

5. Fishing grounds can take spatial prepositions, e.g. Up the Norwest, Out orn ar Milky Tree, Down to the East, Down ar Graveyard.

6. There are fishing grounds that have arisen through humour, e.g. Oodles (where you catch oodles of fish), No Trouble Reef (there are lots of fish in this area so you have no trouble catching fish here), and Horse and Cart. There is confusion as to the history of Ar Yes! / Ikes; either it was named because when the fish start biting, someone once exclaimed 'Ar yes! They're down there', or because it was named after Ike Christian. 10 O'Clock Bank has a similar story - this is the time fish in this area are caught. 
Many fishing grounds have multiple names. For example, Eddys, named after Eddy Yeaman, is also known as Dar (Side) fer Yeamans. Other examples of fishing ground name variants are:

1. Alfreds /Dar Side fer Alfreds / Dar fer Alfreds

2. Ma Nobbys / Dar House fer Ma Nobbys / Dar fer Ma Nobbys / Dar fer Nobbys

3. Graveyard/Dar Graveyard/Down ar Graveyard

4. Milky Tree / Out orn ar Milky Tree

5. Whales Hump / Dar Whales Hump

6. Up the Norwest / Out the Norwest / Up ar Norwest / Out ar Norwest

7. Ar Yes! / Iyes / Ikes / Ikeys / Side fer Iyes

8. Dodos / Ar Side fer Dodos

9. Gun Pit / Ar Gun Pit / Out ar Gun Pit

10. Ar Saddle / Out ar Saddle

Making a distinction between the linguistic status of fishing grounds is not clear. Because these names have developed over time and have developed unofficially, they illustrate a high level of grammatical variability and embedded cultural understanding. Anthroponymous fishing grounds, e.g. Gootys, Alfreds, were named by Norfolk Islanders after Norfolk Islanders. While their formal structure is similar to English forms, the semantic component of names such as Gootys has an insider cultural meme linked to fishing places and the people who fished there. It could be claimed because Gooty was a Norfolk Islander who spoke Norf'k, this name is a Norf'k name. In a similar fashion, the English topographical name Gun Pit can be prefixed with the Norf'k article ar to form the fishing ground name Ar Gun Pit. This would most likely occur when Norfolk Islander fishermen speak Norf' $\mathrm{k}$.

\section{Tagmemic analysis of Norf'k toponyms}

Norf'k toponyms are often obtuse and idiosyncratic; many bear little resemblance to English toponyms, e.g. Johnny Nigger Bun Et (Johnny Nigger Burnt It), Down Side Monty Drown (literally, 'down place Monty drown'), Dar House fer Ma Nobbys (Ma Nobby's House), Out ar Station (Out at the Melanesian Mission Station), Side ar Whale Es (literally 'place the whale is') and Dar Coop (The (Chicken) Coop). Because of the building block or slot-like nature of many Norfolk toponyms, a tagmemic analysis is appropriate. I use tagmemics and a description of slots to indicate whether tagmemes are obligatory or optional. 
In order to test the acceptability of variations in the common Norf'k toponym form, i.e. Dar ... fer ...-S, Norf'k speakers were queried about the acceptability of the six forms. The degree of approval from most favourable to least favourable form was conducted with ten informants. I use the fishing ground name Dar House fer Ma Nobbys (Ma Nobbys House) because it is a typical and prevalent Norf'k toponym form. ${ }^{2}$ There are at most five tagmemes in this form. However, the patterns can be applied to any other Norf'k toponym, comprising the form Dar... fer ...-s. Of the six forms presented below, only the first three were acceptable to my informants, for all toponyms:

1. Dar House fer Ma Nobbys

2. Ar House fer Ma Nobbys

3. House fer Ma Nobbys

4. ${ }^{*}$ Ma Nobbys House

5. *Ar/Dar House fer Ma Nobby

6. ${ }^{*}$ Ma Nobby House

Dar House fer Ma Nobbys differs significantly from the suggestion of the English 'Ma Nobbys House'. Although an equivalent English translation of the Norf'k name rather than the literal 'The House of Ma Nobbys', it was not considered an acceptable Norf' $\mathrm{k}$ form because it did not conform to the common pattern. This name is not used by Norf'k speakers; using the English would not only seem to appear as not conforming to the system, but comprises a variant of the name which would not be considered Norf'k.

The use of ar or dar has no structural, functional or semantic significance apart from possible pragmatic marking of specificity by the use of dar, e.g. 'which house? Dar House fer Ma Nobbys'. The form of $\S 3$ indicates that ar and dar are optional. 'Ma Nobbys House' is considered English by Norf' $\mathrm{k}$ speakers and $\S 4$ and $\S 5$ are not considered possible Norf' $\mathrm{k}$ names. The nucleus of the standard Norf'k toponym form consists of five tagmemes with a specific function for each:

\begin{tabular}{|c|c|c|c|c|c|}
\hline Formula: & Article & $\begin{array}{l}+ \text { Generic } \\
\text { Noun }\end{array}$ & + Preposition & $\begin{array}{l}+ \\
\text { Proper } \\
\text { Noun }\end{array}$ & + Possessive \\
\hline \multirow[t]{3}{*}{ TAGMEME } & 1 & 2 & 3 & 4 & 5 \\
\hline & $\begin{array}{l}\text { (a) } \mathrm{Dar} \\
\text { (b) } \mathrm{Ar}\end{array}$ & House & fer & Nobby & $-s$ \\
\hline & The & House & of & $\begin{array}{l}\text { Ma } \\
\text { Nobbys }\end{array}$ & POSS \\
\hline
\end{tabular}

2 I analyse 'Ma Nobbys', with optional 'Ma', as a single lexical unit. 'Ma Nobby' and 'Nobby' are synonymous. 
1. (a) Dar (b) Ar: Form is optional. There are two phonological variants but the forms in free variation are subject to the pragmatic constraint marking specificity. Inclusion is optional except when the conditions in $\$ 2$ occur.

2. House: Inclusion is optional based on a key cultural understanding that the place being referred to is known. If excluded, tagmeme la is obligatory.

3. Fer: It is obligatory in all cases except when only tagmeme four and five are present. Realisation does not change form.

4. Ma Nobby: Inclusion is obligatory. This tagmeme is always a male or female proper noun, the combination of a name status term like $\mathrm{Ma}$ or $\mathrm{Pa}$ and a proper noun or nickname.

5. $-s$ : Inclusion is obligatory. Realisation does not change form.

Possible syntactic variations are:

$\begin{array}{lllll}\text { 1. } & \text { Dar } & \text { House } & \text { fer } & \text { Ma Nobbys } \\ \text { 2. } & \text { Ar } & \text { House } & \text { fer } & \text { Ma Nobbys } \\ \text { 3. } & - & \text { House } & \text { fer } & \text { Ma Nobbys } \\ \text { 4. } & \text { Dar } & - & \text { fer } & \text { Ma Nobbys } \\ \text { 5. } & - & - & - & \text { Ma Nobbys }\end{array}$

Forms which are not possible are:

$\begin{array}{lllll}\text { 1. } & { }^{*} \mathrm{Ar} & - & \text { fer } & \text { Ma Nobbys } \\ \text { 2. } & \text { * Dar } & \text { House } & \text { fer } & \text { Ma Nobbys } \\ \text { 3. } & \text { * Dar } & - & \text { fer } & \text { Ma Nobbys } \\ \text { 4. } & { }^{*} \mathrm{Ar} & - & \text { fer } & \text { Ma Nobbys }\end{array}$

The tagmemic analysis accounts for all toponyms adhering to the five-tagmeme forms. This system can be applied to generics such as 'side' (place), e.g. Dar Side fer Honeys, pine, e.g. Dar Pine fer Robinsons, and pool, e.g. Dar Pool fer Helens. The analysis shows that tagmemes $\S 1 \mathrm{a} / \mathrm{b}, \S 2$ and $\S 3$ comprise the core syntactic element of this toponym form. The combination of tagmemes $\S 4$ and $\S 5$ constitutes the semantic or cultural element of these toponyms. When the generic element represented by the tagmemes $\S 1$ a or $\S 1 b, \S 2$ and $\S 3$ or $\S 1$ a and $\S 3$ are present, the core semantic element appears sequentially second. This has implications for understanding the relationship between Norf'k syntax, semantics and social dynamics on Norfolk Island, i.e. what is semantically central does not necessarily appear sequentially first.

Patterns from the tagmemic analysis pose the semantic element ( $\$ 4$ and $\S 5$ combined) as central to the social and historical meaning of a toponym. Names such as (Dar Side fer) Martys, (Dar fer) Johnnies and (Dar Pool fer) Helens emphasise the personal (semantic) element of toponyms, and the part they play 
in understanding toponym location, spatial description and history within the social ecology of Norfolk. The analysis reveals that a core syntactic element is related to a core semantic element. It emphasises the difference between the interrelatedness of obligatory and culturally central aspects and optional aspects that are culturally peripheral.

\section{Ar Yes! / Ikes}

Borrowing from Heidegger, Ingold's (2000: 172-188) 'dwelling perspective' emphasises the need to evaluate toponyms in terms of how people construct notions of self, personhood and identity. I use the fishing ground name doublet Ar Yes! / Ikes to illustrate how social worlds and 'neighbourhood' - i.e. situated communities - are created through place-knowledge and how the intricacies of these names are partial descriptions of the toponymic ethnography of the Norfolk Islanders. Ar Yes! / Ikes explicates how such names and linguistic ephemera become embedded in landscape through the localisation of intricate cultural knowledge.

Ar Yes! / Ikes, north-west of Phillip Island in The Passage, has two possible histories. A Norfolk Island informant explained:

The reason this ground is called Ar Yes! is because when your line hits the bottom and the fish start biting, you say 'Ar yes! They're down there!' There are two marks. The first lines up the pine trees on Collins Head across High Point on Nepean, and the second one involves travel west until a little rock on Phillip Island comes out in the cliff like a head. It's about three or four miles from 10 O'Clock Bank. You mainly catch trumpeter, sweet lip (red emperor), and red snapper there. Ikes, another name for the same ground, refers to Isaac 'Ike' Christian. Iyes is another name for the same place. (Bev McCoy, Norfolk Island, February 2008)

Side fer Ikes/Iyes was also elicited according to patterns presented in the tagmemic analysis.

Ar Yes! / Ikes is still known to many Norfolk Island fishermen. No informants knew who had originally named this place. It can be assumed, however, that it was one of the most frequented fishing grounds, as several informants knew of it. The name and the place are connected to a much larger cultural and toponymic network. The fact that it is unknown outside of fishing history and fishing name usage on Norfolk Island means this name 'belongs' to a particular network of people, names, and relationships. A past exists in this name, linked to a particular event (ar yes!) and person (Ike), and these activities and remembrances occur within or with reference to this specific place and name. The name Ar Yes! / 
Ikes animates the event and person Ike as an actor, something or somebody represented and recalled in and through landscape. Ultimately, the doublet is a cultural description of place - it also poses a name as a lineage of knowledge and information that is used pragmatically during daily fishing life and livelihood.

Basso's (1996) place theory presents names as living things within Apache metalinguistics. Living names then can be considered 'healthy' and 'vital' linguistic, social and cultural property. Ar Yes! / Ikes lives in a similar way because the name remains a positive cultural and linguistic artefact for the memory of the event of catching fish and Ike in the minds of Norfolk fishermen. It is known through the activity of fishing and interacting with other fishermen. There appear to be no specific social prohibitions to passing knowledge of this place to others, but Norfolk fishermen are often reluctant to disclose such information to the uninformed or those who do not have any need to know this history - that is, they wonder why non-fishers and people who do not use these areas would be interested in knowing this name. Names and locations of fishing grounds are particularly guarded as such names articulate closely with the political economy of subsistence and small-scale commercial fishing on Norfolk. Those with knowledge of such places, in particular their locations, are then viably able to access the resources therein. There are certain people who are long term residents of Norfolk Island, generally mainlanders, who fish regularly and yet are generally not told about such locations.

Myers' (1986) perspective on language, self, and the solidification of identity in and on landscape can be applied to this fishing ground. It is assumed Ike himself did not name Ar Yes! / Ikes but rather others endowed the place with his name. They have linked and materialised - that is, made durable through mnemonic practices - Ike's self and identity to this place through naming. Linking through naming renders this fishing ground into the historical and linguistic landscape of Norfolk. Ike, the person, is made real through linguistic means - the name Ar Yes! / Ikes - and through embodied practices of using, inhabiting, and moving through place - the name is remembered and the place personalised, localised, and created.

From Ingold's (2000) 'dwelling perspective', Ar Yes! / Ikes as a place and a person comes into being as an agent in a particularised social and ecological setting. Ingold is careful to distance his 'dwelling perspective' from what he calls a 'building perspective'. This building perspective rests on an assumption that human meaning is separated from substance; that is, meaning is inscribed on the natural (real) environment from a separate (virtual) plane of mental representation (2000: 178). From this perspective, as Ingold states, "worlds are made before they are lived in ... acts of dwelling are preceded by acts of worldmaking" (2000: 179). The building perspective therefore presents a pre-existent natural world overlayed by a tapestry of human meaning that precedes interaction with the environment. Meaning in 
this perspective must be created in consciousness and affixed to the environment prior to any human engagement with it (2000: 177, 191). Ingold posits we may better understand the relationship between human beings and their environments - and the forms they build in their imaginations or in the physical world - by beginning with the context of their practical relationship and involvement in their surroundings (2000: 5, 177).

Linguistic worlds are created and affixed to objects in the environment before the users of a language interact with it. Language, in this sense, exists in a mental space separate to the environment. This division appears all the more stark when considering the settlement of the Pitcairn Islanders from a building perspective; the Pitcairners brought Pitkern to a new environment (Norfolk Island) and affixed meaning to it on the basis of existing cultural schemas. An ecolinguistic perspective, on the other hand, does allow these processes of affixing to be seen as preceding or fully separable from experiences of living and dwelling in this environment. Following Ingold's parallel argument about home construction (2000: 186), I assert while humans have the capacity to envision and consider linguistic forms "in advance of their implementation", they can not merely import these forms into the world from a mental location completely detached from it, their thoughts are inseparable from their unavoidable inhabitation of that same world.

While place-naming could be conceived of in a Saussurean sense as the act of attaching of pre-envisioned linguistic forms to undifferentiated space, acts of naming similarly cannot be detached from human activity and their engagements with their environments. The name Ar Yes! / Ikes has become embedded and immersed in a living lifeworld and is signified by the fact that it exists and is used. People privy to this name can locate, interact with and move through these worlds created by and within the world created by Ar Yes! / Ikes. This perspective sees toponyms, and here Ar Yes! / Ikes, metaphorically as names and processes existing within the world (in a place) - in the minds of a select group (language and thought) and in an actual place, although this place, or acculturated space, cannot be set apart or seen aside from the people who interact with it. The name, the memory, the person, the place, and the location of the place and the fishing activities associated with the place 'dwells' and lives in the minds and actions of the people who use the name. The linguistic manifestation of Ar Yes! / Ikes - the formal structure and semantics - is only one element in understanding and realising the importance of the pragmatic usage of the name, what the name represents and the realisation of where the name exists and 'dwells'. The placename itself must be located within the series of contemporary and historical social relationships and activities that enliven it as a place.

Carter (1988) offers a historical cartographic perspective that can be employed to understand the placement of Ar Yes! / Ikes within the historical creation of 
Norfolk toponymic history. The creation and use of the name Ar Yes! / Ikes is a method to claim toponymic space (Crocombe 1991). It is also a method of culturally loaded and embedded linguistic colonisation. It is through knowledge of names via the conduit of language that place-knowledge involves and implies a greater access to and increased 'right' to use the place. Place-knowledge and language use is articulated through and connected with the political and social economy of placenames - the stakes related to knowing and 'unknowing' names also involve access to the location of the fishing ground and the use of the fishing ground. Carter (1988) argues colonising occurs through mapping and creating places from spaces. This process is made clear by and through naming - the personification of names and the processes of naming are methods of 'microcolonisation' that have become remembered. Those who remember the name re-enact the colonisation of the name and the place-space the name represents. There is a degree of ownership associated with the knowing of names, their location in time-space and the mental and physical maps of these places that come to be used.

\section{Coming back to shore}

The esoteric nature of fishing ground names on Norfolk Island represents the role toponyms play in establishing ecological links to place and people through language. Many fishing ground names are semantically transparent and are readily remembered by informants. However, if the history of a name is forgotten, it can still be affixed to the offshore landscape.

The process of acquiring fishing ground names on Norfolk Island took a significant amount of time. This reflects the degree of apprehension about giving insider information to outsiders. Norfolk Island toponymy is insular and inaccessible to outsiders, its anglers obtuse. This could be due to Norfolk's remoteness, its much more marked ethnic and cultural boundaries, and the result of English and Norf'k toponyms creating a complex linguistic ecology.

Norfolk Island fishing ground names are indeed a part of an insular toponymy: they are an extremely guarded element of Norfolk's linguistic and social past. Large amounts of this history have been lost because such knowledge was never documented. It is likely that taking large amounts of toponymic knowledge to the grave, in the past and possibly still in the present, is in accordance with wellestablished cultural memes which solidify stark insider-outsider dichotomies of Norfolk's insider society. Moreover, such dichotomies emphasise the strong societal allegiances on Norfolk through restricting access to the transmission of toponymic knowledge to outsiders, whether they are from outside Norfolk or outside the respective circle which is granted access to this knowledge. It 
is possible Norfolk's acceptance of its stronger historical and cultural ties to Britain, Pitcairn Island, and Tahiti rather than to Australia and to a lesser extent New Zealand exacerbates some of the suspicion outsiders from the inner core of Norfolk society feel when attempting to access linguistic information like toponyms. A quote by Latham (2005: 41) succinctly summarises the insularity of Norfolk Island society:

[I] did want to try and understand what made the place tick. It made me wonder if Norfolk Island really wanted to be understood. No one ever said jump in my truck or boat and I'll show you what's important to me. No one offered to show me their island, their world, the one they so desperately wanted to protect and honour. I was never invited to anything by an elected representative of an island which claims to be misunderstood, misrepresented and maligned by mainland media and politicians. I got the feeling it enjoyed its ambiguity, it helped cloud everything over. 'It takes time to understand this island,' locals kept saying, which is not surprising because so few were willing to explain it. (Latham 2005: 41)

\section{References}

Acheson, J.M. 1981, 'Anthropology of fishing', Annual Review of Anthropology 10: $275-316$.

Administration of Norfolk Island, 2004, Norfolk Island Language (Norf'k) Act 2004, Administration of Norfolk Island, Norfolk Island.

Basso, K.H. 1996, Wisdom Sits in Places: Landscape and Language among the Western Apache, University of New Mexico Press, Albuquerque.

Blair, S.L. 2006, 'Shooting a net at "Gilly's Snag": the movement of belonging among commercial fishermen at the Gippsland Lakes', unpublished PhD thesis, University of Melbourne.

Capel, D. 1977, Dave Capel's 50 Favourite Offshore Fishing Spots, Advanced Marketing, Adelaide.

Carter, P. 1988, The Road to Botany Bay: An Exploration of Landscape and History, Faber \& Faber, London.

Crocombe, R. 1991, 'Naming and claiming in the South Pacific', Journal of the Pacific Society 14(1): 216-234. 
Forman, S. 1967, 'Cognition and the catch: The location of fishing spots in a Brazilian coastal village', Ethnology 66(4): 417-426.

Gaffin, D. 1996, In Place: Spatial and Social Order in a Faeroe Islands Community, Waveland Press, Prospect Heights.

Green, T. H. 1973, 'Petrology and Geochemistry of Basalts from Norfolk Island', Journal of the Geological Society of Australia 20(3): 259-272.

Hardy, W. 1974, The Saltwater Angler, Fifth edition, Murray, Sydney.

Hovda, P. 1961, Norske Fiskeméd: Landsoversyn og to gamle médbøker.: Universitetsforlaget, Oslo.

Ingold, T. 2000, The Perception of the Environment: Essays in Livelihood, Dwelling and Skill, Routledge, London.

Johannes, R.E. 1981, Words of the Lagoon: Fishing and Marine Lore in the Palau District of Micronesia, University of California Press, Berkeley.

Kurlansky, M. 1999, Cod: A Biography of the Fish that Changed the World, Vintage, London.

Latham, T. 2005, Norfolk: Island of Secrets: The Mystery of Janelle Patton's Death, Allen \& Unwin, Crows Nest, NSW.

Mühlhäusler, P. 2006, ‘The Norf‘k language as a memory of Norfolk's cultural and natural environment', in Referred Papers from the 2nd International Small Island Cultures Conference, H. Johnson (ed.), Small Islands Cultures Research Initiative, Sydney: 104-111.

Mühlhäusler, P. 2007, 'The Pitkern-Norf'k language and education', English World-wide 28(3): 215-247.

Myers, F.R. 1986, Pintupi Country, Pintupi Self: Sentiment, Place, and Politics among Western Desert Aborigines, University of California Press, Berkeley.

Nash, J. 2011, 'Insular toponymies: Pristine place-naming on Norfolk Island, South Pacific and Dudley Peninsula, Kangaroo Island, South Australia', unpublished $\mathrm{PhD}$ thesis, University of Adelaide. http://digital.library. adelaide.edu.au/dspace/handle/2440/71015.

Tyrell, M. 2006, 'From placelessness to place: an ethnographer's experience of growing to know places at sea', Worldviews 10(2): 220-238.

UNESCO 2007, Degree of Endangerment of the Norf'k Language (Norfolk Island, South Pacific), document. 
This text taken from Indigenous and Minority Placenames: Australian and International Perspectives, Edited by Ian D. Clark, Luise Hercus and Laura Kostanski, published 2014 by ANU Press, The Australian National University, Canberra, Australia. 